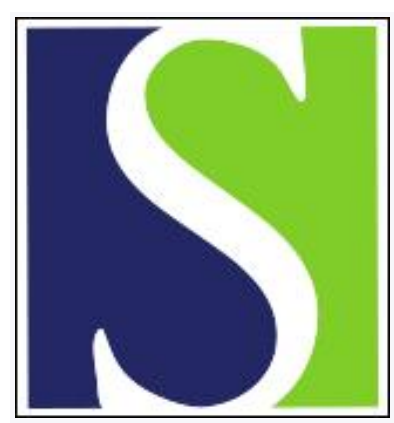

Scand J Work Environ Health 1986;12(4):359-361

https://doi.org/10.5271/sjweh.2146

Issue date: Aug 1986

Transmission of hand-arm vibration to the head.

by Sakakibara H, Kondo T, Miyao M, Yamada S, Nakagawa T, Kobayashi F, Ono Y

This article in PubMed: www.ncbi.nlm.nih.gov/pubmed/3535062

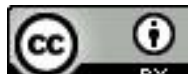




\title{
Transmission of hand-arm vibration to the head
}

\author{
by Hisataka Sakakibara, MD, ${ }^{1}$ Taka'aki Kondo, MD, ${ }^{1}$ Masaru Miyao, MD, ${ }^{1}$ Shin'ya Yamada, MD, ${ }^{1}$ \\ Takeo Nakagawa, MD, ${ }^{2}$ Fumio Kobayashi, MD, ${ }^{3}$ Yuichiro Ono, $\mathrm{MD}^{4}$
}

\begin{abstract}
SAKAKIBARA H, KONDO T, MIYAO M, YAMADA S, NAKAGAWA T, KOBAYASHI F, ONO Y. Transmission of hand-arm vibration to the head. Scand $J$ Work Environ Health 12 (1986) 359-361. A "tooth impression" was devised to measure head vibration. The vertical head vibration of four subjects was measured with the tooth impression during exposure of the hand to vertical sinusoidal vibration at acceleration levels of $3.15,10.0$, and $31.5 \mathrm{~m} / \mathrm{s}^{2}$ root mean square in the range of $8-200 \mathrm{~Hz}$. While in a standing position, the subjects pulled the vibrating handle upward at a force of $5 \mathrm{~kg}$ with the elbow joint stretched during the tests. The measurement was repeated twice. The difference between the two measurements was within $3 \mathrm{~dB}$, a level which suggests that this method has good reproducibility. The vibration transmitted to the head was the greatest in the range of $12.5-16 \mathrm{~Hz}$, and the attenuation was about $20 \mathrm{~dB}$. Head vibration decreased by approximately $15 \mathrm{~dB}$ per octave at frequencies above $20 \mathrm{~Hz}$ as the frequency increased. When the excitation level was increased by $10 \mathrm{~dB}$, the head vibration increased by about $8 \mathrm{~dB}$.
\end{abstract}

Key terms: attenuation, head vibration, measuring method, vibration transmission.

It is important to understand the transmission of handarm vibration to the human body so that its effects can be estimated. There is, however, some difficulty in measuring vibration in the human body because of the resiliency of the skin and muscles (11). Hence various methods have been devised to fix accelerometers on the body rigidly. In some studies accelerometers have been attached directly to the bone (11).

A "tooth impression" was devised to measure head vibration. It is closely set in the incisors. Head vibration is measured by small accelerometers fixed to the tooth impression. A previous study (6) revealed that the method has high reproducibility. In the present study the vibration transmitted to the head was measured with the use of a tooth impression during exposure of the hand to vibration.

\section{Subjects and methods}

Four subjects (aged 21 to 31 years) were tested.

Sinusoidal vibration was produced by an Akashi ASE12 electrodynamic vibrator. The acceleration of the vibrator was recorded by an accelerometer (Rion, VM-17) attached to the handle of the vibrator. The acceleration of the head was measured by an accelerometer (Imv, VP-4132, $5 \times 5 \times 11.5 \mathrm{~mm}, 1 \mathrm{~g}$ weight) on a tooth impression set in the upper central incisors.

\footnotetext{
1 Department of Public Health, Nagoya University School of Medicine, 65 Tsurumai-cho, Showa-ku, Nagoya, Japan.

2 School of Physical Education, Chukyo University.

${ }^{3}$ Department of Hygiene, Aichi Medical University.

+ Department of Hygiene, Nagoya University School of Medicine.
}

Reprint requests to: Dr H Sakakibara, Department of Public Health, Nagoya University School of Medicine, 65 Tsurumaicho, Showa-ku, Nagoya, Japan.
A tooth impression, to be fitted to the upper incisors of each subject, was made from resin prior to the tests. The size of the tooth impression was about $20 \mathrm{~mm}$ long by $15 \mathrm{~mm}$ wide by $12 \mathrm{~mm}$ thick, and the weight was about $2 \mathrm{~g}$. The surfaces were flat except for the top and the sides, where the shape of the incisors was imprinted.

The force of pulling the handle of the vibrator was measured by strain gauges attached to the handle. The output voltage of the strain gauges was recorded with an output indicator (Watanabe, DS-1L). The subjects kept the pulling force constant during the tests by watching the indicator.

While in a standing position the subjects pulled the handle upward at a constant force of $5 \mathrm{~kg}$ with the elbow joint stretched during the tests. The right hand was exposed to vertical sinusoidal vibration at acceleration levels of $3.15 \mathrm{~m} / \mathrm{s}^{2}$ root mean square $(\mathrm{rms})$, $10.0 \mathrm{~m} / \mathrm{s}^{2} \mathrm{rms}$, and $31.5 \mathrm{~m} / \mathrm{s}^{2} \mathrm{rms}$ in the range of $8-$ $500 \mathrm{~Hz}$ at intervals of the one-third octave band. Vertical head vibration was measured under these conditions. The measurement of each subject was repeated twice (figure 1).

Head acceleration was recorded by a portable cassette recorder (Teac, R-70). The data were analyzed by a one-third octave-band analyzer (Rion, SA-59A). Because of the capacity of the vibrator and the measuring apparatus, the analysis was limited to the range of $8-80 \mathrm{~Hz}$ at the excitation level of $3.15 \mathrm{~m} / \mathrm{s}^{2}$ $\mathrm{rms}$, of $25-125 \mathrm{~Hz}$ at the level of $10.0 \mathrm{~m} / \mathrm{s}^{2} \mathrm{rms}$, and of $40-200 \mathrm{~Hz}$ at the level of $31.5 \mathrm{~m} / \mathrm{s}^{2} \mathrm{rms}$.

\section{Results}

The two measurements of each subject under the same conditions were nearly equal, and the difference 


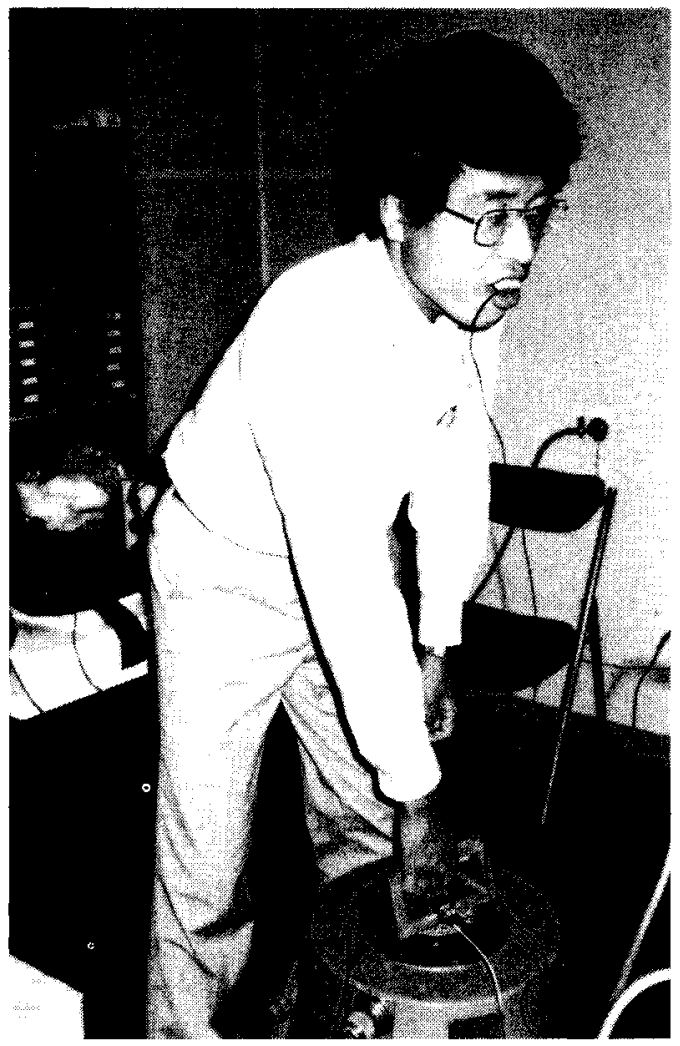

Figure 1. Method for measuring head vibration with a tooth impression.

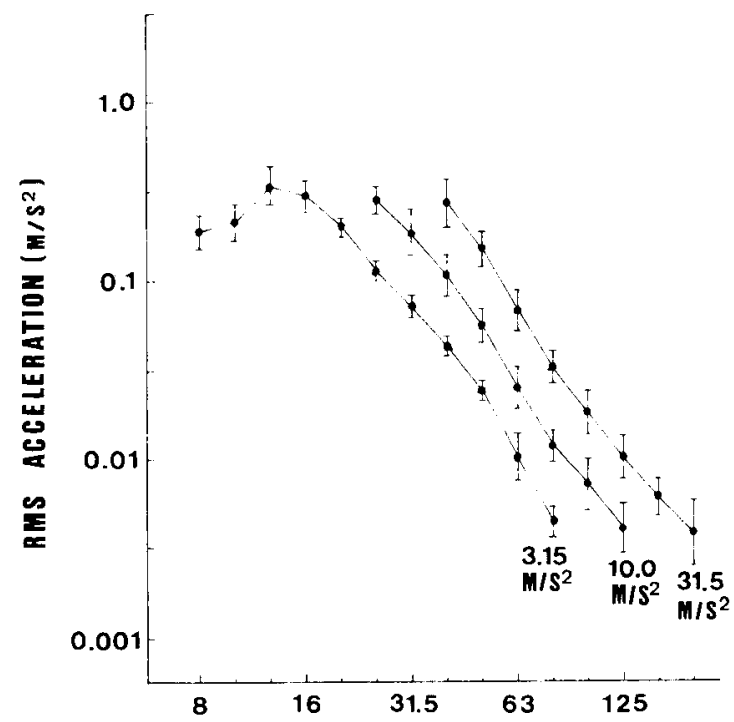

1/3 OCTAVE-BAND CENTER FREQUENCY ( $\mathrm{H}$ )

Figure 2. Vertical vibration (mean $\pm S D$ ) transmitted to the head of the subjects during exposure of the hand to vertical sinusoidal vibration at the acceleration of $3.15,10.0$, and $31.5 \mathrm{~m} / \mathrm{s}^{2}$ root mean square (RMS). (M/ $\mathrm{S}^{2}=$ meters per square second) between them was within $3 \mathrm{~dB}$. There were some differences in the results among the subjects, but the patterns were approximately similar. The vibration transmitted to the head was the greatest at frequencies from 12.5 to $16 \mathrm{~Hz}$, and above $20 \mathrm{~Hz}$ it decreased as the frequency increased.

The vibration transmitted to the head of the subjects and the attenuation between the excitation vibration (handle of vibrator) and the head vibration are shown in figure 2 and table 1 . The head vibration was the greatest in the range of $12.5-16 \mathrm{~Hz}$, and the attenuation was about $20 \mathrm{~dB}$. In the range of $20-125 \mathrm{~Hz}$ at every excitation level the vibration transmitted to the head decreased at the rate of approximately $15 \mathrm{~dB}$ per octave.

When the excitation level was increased by $10 \mathrm{~dB}$, the vibration transmitted to the head increased about $8 \mathrm{~dB}$ at every frequency.

\section{Discussion}

A method for measuring head vibration using a tooth impression was examined in an earlier study (6). The results showed that the method has good reproducibility. In the present experiments the difference between two measurements was also within $3 \mathrm{~dB}$, which was similar to the results of the prior study.

The difference between measurements on the forehead and those on the tooth impression was investigated in earlier studies $(6,8)$. These studies indicated that measurement on the forehead was influenced by the fixing condition of the accelerometers, and the measurement level on the forehead was higher than that on a tooth impression at frequencies below $25 \mathrm{~Hz}$. The results were reversed at frequencies above $80 \mathrm{~Hz}$. The difference may be due to the soft tissue or the position of the accelerometers on the head. The influence of the soft tissue is smaller in measurements on a tooth impression than on the forehead. The influence of the position of the head has been indicated to be due to the difference in angular head movement, such as nodding $(4,10)$ and/or anatomical structure. Eliminating the influence is difficult. But the obvious effects of the head movement should be taken into account. It can be concluded that measuring head vibration with a tooth impression is more accurate because there is little influence from the soft tissue.

Various methods of measuring head vibration have been devised. "Bite-bar" by Griffin (4), "dental bite" by Sandover (10), and "Bei $\beta$ - platte" by Szameitat \& Dupius (12) are similar to our "tooth impression" approach. Griffin reported that the bite-bar method is a highly acceptable and repeatable technique. The difference between their method and the present one is in the way these devices are fixed. For fixation, the former devices must be bit in the mouth, but the latter is closely set in the upper central incisors. Thus, the present method would appear to be superior. 
Table 1. Attenuation between the vibrating handle and the head.

\begin{tabular}{|c|c|c|c|c|c|c|}
\hline \multirow{3}{*}{$\begin{array}{l}\text { One-third octave-band } \\
\text { center frequency } \\
(\mathrm{Hz})\end{array}$} & \multicolumn{6}{|c|}{ Attenuation (dB) } \\
\hline & \multicolumn{2}{|c|}{$\begin{array}{l}\text { At excitation } \\
\text { of } 3.15 \mathrm{~m} / \mathrm{s}^{2}\end{array}$} & \multicolumn{2}{|c|}{$\begin{array}{l}\text { At excitation } \\
\text { of } 10.0 \mathrm{~m} / \mathrm{s}^{2}\end{array}$} & \multicolumn{2}{|c|}{$\begin{array}{l}\text { At excitation } \\
\text { of } 31.5 \mathrm{~m} / \mathrm{s}^{2}\end{array}$} \\
\hline & Mean & $S D$ & Mean & SD & Mean & SD \\
\hline 8 & 24.6 & 1.8 & . & . & & . \\
\hline 10 & 23.5 & 2.1 & . & . & . & . \\
\hline 12.5 & 19.5 & 1.9 & . & . & . & . \\
\hline 16 & 20.5 & 1.7 & . & . & . & . \\
\hline 20 & 23.9 & 1.1 & ${ }^{\circ}$ & . & . & . \\
\hline 25 & 28.8 & 1.2 & 30.9 & 1.5 & & $\cdot$ \\
\hline 31.5 & 32.8 & 1.3 & 34.8 & 2.3 & & $\dot{.}$ \\
\hline 40 & 37.3 & 1.0 & 39.4 & 2.3 & 41.4 & 2.6 \\
\hline 50 & 42.4 & 1.2 & 44.9 & 1.9 & 46.5 & 1.9 \\
\hline 63 & 49.8 & 2.6 & 52.0 & 2.4 & 53.3 & 2.3 \\
\hline 80 & 57.1 & 1.7 & 58.5 & 1.7 & 59.6 & 1.8 \\
\hline 100 & . & . & 62.9 & 2.8 & 64.8 & 2.5 \\
\hline 125 & $\dot{.}$ & . & 67.8 & 2.8 & 69.8 & 2.4 \\
\hline 160 & . & i & . & . & 74.4 & 2.1 \\
\hline 200 & : & . & . & . & 78.4 & 3.7 \\
\hline
\end{tabular}

Denisov (2) examined head vibration under similar conditions in the range of $8-125 \mathrm{~Hz}$ at octave intervals. His results were similar to the present ones in the range of $16-125 \mathrm{~Hz}$ except at $8 \mathrm{~Hz}$. Von Bekésy (1) has reported that the attenuation was about $40 \mathrm{~dB}$ at the frequency of $50 \mathrm{~Hz}$. In the present experiment it was $42 \mathrm{~dB}$ at an excitation level of $3.14 \mathrm{~m} / \mathrm{s}^{2} \mathrm{rms}$. These results were nearly the same except for the low frequency in spite of some difference in the experimental conditions of these studies. For instance, the manner of attaching the accelerometers, the location of the accelerometers, the gripping force, and the excitation level.

The present experiment showed that the vibration transmitted to the head was the greatest at 12.5 to 16 Hz. Iwata et al (5) and Dupuis et al (3) have indicated a resonance at $10-16 \mathrm{~Hz}$ in the wrist and elbow. These findings suggest that the vibration measured in the wrist of our subjects may have been transmitted to the head without any deformation of the frequency distribution, since the subjects kept their elbow joint stretched.

Pyykkö et al (9) have reported that the attenuation recorded in the elbow was almost the same regardless of the excitation level. In the present study head vibration was increased by about $8 \mathrm{~dB}$ when the excitation level was increased by $10 \mathrm{~dB}$. The difference may be attributed to the position of measurement, in the elbow or in the head, and the measuring method. More investigations would be required on this point.

The attenuation between the excitation vibration and the head vibration was about 20 to $25 \mathrm{~dB}$ at frequencies below $20 \mathrm{~Hz}$. Under the present experimental conditions head vibration can be estimated to be approximately 1.0 to $3.15 \mathrm{~m} / \mathrm{s}^{2}$ when the hand is exposed to vibration levels of $31.5 \mathrm{~m} / \mathrm{s}^{2}$. Thus head vibration might affect the human body. These effects should be further investigated.

The vibration transmission to the body is influenced by the grip strength on the vibrator handles $(2,9)$, postures $(4,7,9)$, and other factors. The grip strength and posture vary greatly in the use of vibrating tools. The vibration transmitted to the head would also vary widely. The authors are, therefore, planning to examine head vibration under field conditions.

\section{References}

1. Bekésy G Von. Über die Empfindlichkeit des stehenden und sitzenden Menschen gegen sinusförmige Erschütterungen. Akust Zh 4 (1939) 360-369.

2. Denisov ZI, Sergeev EI. On the transmission of vibration to human body. Gig Tr Prof Zabol 6 (1968) 3-7.

3. Dupuis H, Hartung E, Hammer W. Biomechanishes Verhalten, Muskelreaktion und subjektive Wahrnehmung bei Schwingungserregung der oberen Extremitäten zwischen 8 und $80 \mathrm{~Hz}$. Int Arch Occup Environ Health 37 (1976) 9-34.

4. Griffin MJ. Vertical vibration of seated subjects: Effects of posture, vibration level, and frequency. Aviat Space Environ Med 46 (1975) 269-276.

5. Iwata $H$, Dupuis $H$, Hartung E. Ubertragung von horizontalen Sinusschwingungen auf die oberen Extremitaten bei Halbpronationsstellung und Reaktion des M biceps. Int Arch Arbeitsmed 30 (1972) 313-328.

6. Kobayashi F, Nakagawa T, Kanada S, Sakakibara H, Miyao M, Yamanaka K, Yamada S. Measurement of human head vibration. Ind Health 19 (1981) 191-201.

7. Miwa T. Mechanical impedance of human body in various postures. Ind Health 13 (1975) $1-22$.

8. Nakagawa T, Yamanaka K, Kobayashi F. Measuring the level of vibration on the human body - Transmission of train vibration to the human head in residential house. Jpn J Hyg 38 (1984) 909-913.

9. Pyykkö I, Farkkilä M, Toivanen J, Korhonen O, Hyvärinen $\mathrm{J}$. Transmission of vibration in the hand-arm system with special reference to changes in compression force and acceleration. Scand J Work Environ Health 2 (1976) 87-95.

10. Sandover $\mathbf{J}$. Modelling human responses to vibration. Aviat Space Environ Med 49 (1978) 335-339.

11. Sugg CW. Modelling of the dynamic characteristic of the hand-arm system. In: Taylor W, ed. The vibration syndrome. Academic press, London 1974, pp 169-186.

12. Szameitat P, Dupuis $H$. Uber die beeinflussung des liegenden Menschen durch mechanische Schwingungen. In: Arbeiten aus dem Max-Planck-Institut fur Landarbeit und Bad Kreuznach. 1976 pp 10-62. (A-76-1). 